\title{
Jean Devanny's Fictional Critique of Whiteness and Race Relations in North Queensland
}

\author{
Carole Ferrier
}

\author{
School of English, Media Studies and Art History \\ The University of Queensland
}

\begin{abstract}
Devanny was a largely forgotten and disregarded figure in Australian political and literary history by the 1960s, but the newly revitalised feminist, race-conscious and postcolonial analyses of the 1970s allowed her work a new relevance. Devanny's first novels were written in Wellington in the 1920s, and some feature Maori men in relationships with white women. Her Queensland novels begin when she visited the North engaged in political support for the Weil's disease strike, out of which came Sugar Heaven (1936), and then Paradise Flow (1938) - both of which show white women choosing Migrant men (Italian and Jugoslav) over their white husbands - and after that, a planned cane industry trilogy, of which only the first volume, Cindie (1949), in which the white lady of the house has sex with a South Sea Islander indentured worker, would be published. The (also unpublished) "The Pearlers" offers a depiction of a white patriarch in simultaneous relationships with white and Indigenous women on Thursday Island, where she spent some time in 1948. Devanny moved to Townsville in 1950 to live; she published very little after that, although the already written Travels in North Queensland came out in 1951. The paper will consider how far Devanny can be viewed as working with an early style of 1990s "whiteness theory", and also how, in this regard, one might think about her depiction (often scanty) of Indigenous characters in her north Queensland fictions.
\end{abstract}

D ominant Australian views of racial difference, desirable populations and national characteristics were a complicated matter in the late-nineteenth and earlier twentieth centuries, in which the three novels I discuss in this paper are set. A useful frame for investigating them is the critical whiteness studies perspectives that have emerged and developed from the 1990s: ${ }^{1}$ as Jan Larbalestier put it in 2004, "Whiteness as a metaphor for relations of domination, and as a normative framework for comprehending the world, is clearly pervasive in debates about the past" (Larbalestier 50). One key factor that influenced the "essentialist racism" that often lay behind the "white man's burden" of European imperialism and colonisation was the requirement for a labour force for developing industries, especially, in north Queensland, the cultivation of sugar cane. From the 1860s until their deportation with the introduction of the White Australia Policy around the time of Federation (along with a ban on Asian immigration), this labour force was made up substantially of South Sea Islander indentured workers. ${ }^{3}$ Asian workers, especially Chinese, were quite prominent in agriculture.

\footnotetext{
${ }^{1}$ Early works that appeared in the 1990s are Toni Morrison's Playing in the Dark: Whiteness and the Literary Imagination (1993); Richard Dyer's White (1997); and Ruth Frankenberg's White Women, Race Matters, 1993, and Displacing Whiteness, 1997. In Australia, much discussion in this area has been published in the Critical Race and Whiteness Studies Journal.

${ }^{2}$ Frankenberg's White Women, Race Matters talks of three modes of white subjectivity-"each at different stages takes centre stage as the organising paradigm, or retreats to the status of a repertoire" -essentialist racism, colour and power evasiveness or blindness, and race cognisance (Frankenberg 169).

${ }^{3}$ Kanakas was the term in widespread use at the time, but I have used the term "Islanders" through this
} 
The labour force in the following period was substantially European migrants, in particular, many Italians. The Indigenous population was another source of labour power, but it was mainly deployed in the pearling and trochus industries and in stockwork; as well, there was a huge force of mainly female domestic servants. My discussion focuses mainly upon Jean Devanny's novel, Cindie (1949), set in north Queensland, its sequel, "One Can't Have Everything" "which was never published, and a novel set on Thursday Island, "The Divers, the Devil and Pan, or, Pearls and Baroque,"5 which also never found a publisher. These novels provide different depictions of South Sea Islanders, and of Aborigines and Torres Strait Islanders, and their complex relationships to white Australia as well as revealing a wider, although sometimes muted (for reasons discussed below), critique of white colonial attitudes.

In 1927, Raphael Cilento wondered, in The White Man in The Tropics, if north Australia should even be described as tropical, since there was "no teeming native population riddled with disease"; it was, rather, he considered, "occupied by many thousands of pure-blooded European settlers" (Cilento 8, 10, qtd. Anderson 136). Similarly, William Morris Hughes, in The Splendid Adventure, "had a vision of one hundred million or more thriving and pure whites populating the whole continent" (Anderson 164), but was concerned about Australia being "a white island in a vast coloured ocean," and needing to build "dykes through which the merest trickle of the sea of colour cannot find its way" (qtd. Anderson 164). In spite of these anxieties, the capitalist compulsion to find workforces to build up industries operated to modify nineteenth-century genocidal $^{6}$ or exclusionist attitudes and practices. Part of the picture was also the issue of whether the whiteman could work in the tropics. ${ }^{7}$ In relation to the north of Australia, Fleetwood Anderson asked in 1926, in Australia-White or Yellow, "Is there any prospect that the white man will succeed in obtaining returns on these regions at a level with those which the yellow or brown man could obtain?" (qtd Anderson 164) ${ }^{8}$ : a question to which he expected a negative reply. Such commentators seem blindfolded by their own constructions of whiteness.

article to signify Melanesian Islanders. In Sandwich Islands dialect, Kanaka signified the general concept of "man" but it soon acquired the same derogatory overtones as the terms "nigger" and "boy." The first indentured workers arrived in 1863, initially for cotton growing. 2013 marks the $150^{\text {th }}$ anniversary of these first arrivals.

${ }^{4}$ There are several typescripts of this novel in the Eddie Koiki Mabo Library, James Cook University. Quotations are from JD/MSS/26/1; I also make reference to the revised version, "You Can't Have Everything," JD/MSS26/5. This text, with the pen name Harry Groves, also explicitly identifies Mossman as the area of north Queensland to which the Biddow family initially moved.

${ }^{5}$ This exists in three typescript drafts in the Eddie Koiki Mabo Library; the quoted pages below are from JD/MSS/25/1; with one from the second draft, The Pearlers or The Pearlers and Pan, JD MSS/25/2.

${ }^{6}$ See Rothwell's review of Timothy Bottoms's Conspiracy of Silence for a summary of some of the massacres of Aboriginal people, documented in his book. The Commonwealth of Australia's Bringing Them Home report documents the "stolen children" and the "stolen wages."

${ }^{7} \mathrm{~J}$. A. Nilsson notes that, in 1872, a group of Scandinavian labourers were brought in to cut cane but failed to adjust to the conditions (359).

${ }^{8}$ In fact, Clive Moore estimates that 15,000 transported Islanders died in Queensland (qtd, Voices of Melanesia). In Point of Departure, Devanny notes that one of her main informants regarding Islander history was the Reverend Taft, who told her that "the main lack in Cindie ... was that insufficient stress was laid upon the fact that the Kanakas died like flies of measles and chest complaints" (301). Moore also calculates that their "stolen wages," never returned to their communities, would approximate today around $\$ 30-35 \mathrm{~m}$. 
Whiteness studies involves recognition of Anglo-Celticity as a racialised identity like any other, rather than the naturalised and taken-for-granted dominance of white cultural values (upon which Western nations built their colonial, and postcolonising power). It is, accordingly, useful to examine fictional representations for the ways in which such a difference of view might be seen as coming into play. Aileen Moreton-Robinson in 1999 argued that it was necessary "to deconstruct and racialise whiteness to offer useful insights about power relations in Australian society" (6). She identified whiteness as operating in two key areas: "that of subjectivity, and that of institutional practice within the centre" (1-2). In the papers from the "Deconstructing Whiteness" conference held at the Queensland Studies Centre in 1998, she argued that when the gaze is reversed, "white people are visible and are perceived by Indigenous people as having a collective racial identity" (Moreton-Robinson 3).

Moreton-Robinson, in relation to whites writing about non-whites, calls for attention to "the impact of whiteness on white writers and their craft" (3), ${ }^{9}$ and this provides a useful frame through which to look back at Devanny's representation of race and ethnic relations ${ }^{10}$ in her planned trilogy of the north Queensland sugar industry. ${ }^{11}$ I will do this through a focus on the representation of non-white characters, the lines of plot that depict the personal and power relationships between these characters from different backgrounds, and the uses of language to designate particular groups. One aspect of some interest is the prejudices of various minority populations regarding each other, as they are voiced within the context of hegemonic AngloCeltic ideologies of white supremacy. In late nineteenth-century Queensland, the setting for Devanny's Cindie, ${ }^{12}$ we can identify several features of the racialised landscape, in which discrimination on the grounds of race and ethnicity rules. Aboriginal labour only slowly entered the waged economy. ${ }^{13}$ The Chinese and other South East Asians were another significant early group of migrant workers, but Italians and other European migrants feature centrally in the second volume (as they did in Devanny's 1936 Sugar Heaven), since they had substantially

\footnotetext{
${ }^{9}$ Moreton-Robinson also considered, however, that while by then much academic practice was increasingly referencing Indigenous or non-white voices, this has often had the effect of recentring whiteness (3-4). This problem has also been engaged with in the work of Sara Ahmed, and others. For Ahmed, "the project of making whiteness visible only makes sense from the point of view of those for whom it is invisible" (1) ${ }^{10}$ Devanny's own interest in issues of race and ethnicity can be read in her earlier fiction set in New Zealand, and her investigation into, and conscious intention of combating what was then called "chauvinism" had a long pre-history in her writing from the mid-1920s-on.

11 I have discussed elsewhere (Borch 2008) other writers who deal with this, and what might be the difference of view of those with South Sea Islander heritage-Faith Bandler in Wacvie (1977) and Welou My Brother (1984), and Noel Fatnowna in Fragments of a Lost Heritage (1989), for example.

${ }^{12}$ Devanny finished Cindie in 1945 and sent it to Curtis Brown (Ferrier 1992, 125). Although she was told it was "immediately accepted, to come out within a year" (MF to JD, 6.1.1947, Ferrier 1992 160), it was still being delayed when Curtis Brown wrote to JD, on 15 December 1948, that "the printers seem to feel that some of the love scenes border on the licentious and might conceivably get them into trouble" (Ferrier 1992, 204).

13 Devanny's planned trilogy of the canefields, of which only the first volume was published and only the first and second written, parallels interestingly Katharine Susannah Prichard's Western Australian Goldfields trilogy (published between 1946 and 1950), including its depiction of Indigenous people. The most famous depiction of an Indigenous woman is, of course, in Prichard's Coonardoo (1929).
} 
replaced the earlier workforces on the cane fields. The pearl shell industry built up rapidly from the 1870s and 80s in the Torres Strait and, by 1890, the Torres Strait supplied half of the world demand. In earlier years, Japanese indentured labour was dominant in the industry, later, many Japanese were interned during the Second World War.

In the 1880s and 1890s, the fervent debates about indentured labour revealed a conflict of various economic and political interests in the replacement of Kanaka (and Asian, especially Chinese) workers with European labour in cane cutting. Devanny fills in some details of these debates, and also mentions the widespread racism in the labour movement: exemplified in and fostered by William Lane's the Worker, and the Bulletin. ${ }^{14}$ In Cindie, Devanny mentions that Blanche's Tory father, Tom Hilliard, was friendly with William Lane in earlier years, and was familiar with his desire to have "every dirty skin, black or yellow" removed (Cindie 64). Kay Saunders suggests that "a different and more vicious stereotype predominated during the last phase of indenture" when "later working-class authors had changed the racial emphasis from that of a predominantly political and economic threat to a sexual and social one" (Evans et al, Exclusion, 221).

Cindie focuses mainly on Islander labour ${ }^{15}$ and the Indigenous people. The main characters are Randolph Biddow and his wife, Blanche, squatters who employ Islanders in the period covered by the novel, 1896-1907. They have two young children, Irene and Randy. On the first page of the novel, boats arrive at the wharf bringing Biddow's wife and children, and six Islander labourers, ${ }^{16}$ regarding whom one of the men standing on the wharf says, "They have brought your niggers, all right, Randolph" (5). ${ }^{17}$ The Biddows are to stay with the Callaghans, their

\footnotetext{
${ }^{14}$ See Evans, "Anti-Chinese Riot, 1888,"and Kellett, "The Boomerang," Evans et al. eds., Radical Brisbane 2004: 66-70, 71-75.

${ }^{15}$ Devanny puts the figure for labourers at 50,000 Kanakas (see note 3 above) and 500,000 whites at the turn of the century (Cindie 138). After December 1890 no more Islanders were brought into the Colony. Almost all Islanders were to be repatriated by 1906, but mass deportations continued into 1907 . This brought to an end a period in which 60,000 Islanders were brought to Queensland, more than a third of them by nefarious or illegal means.

${ }^{16}$ Randolph tells Blanche soon after they arrive, "I've applied to the Government for another twelve kanakas and Mr Callaghan has applied for a couple of dozen Hindus. He believes that Hindus cut the cane better than Kanakas" (28). Later we find out that the neighbouring Montague property, Glenelg, has 150 Chinese workers and 50 Kanakas, but that "Montague's small army of Celestials in the main would return to China, following in the wake of thousands of their countrymen who, having been lured from their native land by the promise of wealth from the Mountain of Gold - their homeland name for the mighty Queensland colony - had actually realised their expectations and, with the goldfields gutted, returned to their Flowery Land" (60).

${ }^{17}$ Many of the characters use this term. They are admonished for it by Biddow and Cindie in the course of the novel. Mary Gilmore's reaction to Hewett's novel, "The Wire Fences of Jarrabin," as reported in Wild Card, is also of interest in this regard:

"Why do your characters refer to the Aborigines as "niggers"? No Australian has ever referred to an Aborigine as a "nigger.""

"They did where I come from", I venture ...

"Australians are not racists ... Your story is not good. I advise you to throw it away." (Hewett 253.)
} 
neighbours, until their house is built. Cindie comes with Blanche, initially as her (white) maid, to the north Queensland plantation. She is puzzled about "why the mistresses worked when so many servants were at hand. Toby, now. There she sat, lolling on a chair, staring at Cindie while Consuela made the coffee and piled the tray" (19). She asks why the Aboriginal maid, Toby, is not doing it, "Is she too stupid?" Consuela replies, "I don't think so. But she pretends she is because she doesn't like work ... Our black girl, Alice, is at the camp on the creek, having a baby. She got too friendly with a Kanaka, I think" (19).

As they walk around the house and gardens, Cindie observes the arrangement of the different accommodation and facilities. These include small rooms for Toby and for Funwala, "the young Kanaka" who drives the sulkies, is "Mary Callaghan's protégé" and, accordingly, eats with the white workers (46); the dining room for "the two dozen kanakas maintained by the plantation"; and the "quarters for the four white workmen." The cookhouse has quarters nearby for "two field cooks, a Chinese named Lo How, and Yamada, a Japanese" (18). The Islanders live in shacks beyond, "each surrounded by a garden plot" (22).

Two black women are seen working in their gardens. Mary Callaghan tells Cindie that one of them, Mary, is the only female Islander; the other is "an Aborigine married to a Kanaka" (23); we find out later she is called Minnie. These women rush their two small children into the house when the whites approach. Irene cries, "Mother, the little niggers had no clothes on!" and Blanche responds, "They are only little niggers, you know, darling. They don't know any better." (23) Mary is married to Tommy, a Methodist preacher - and "a remarkably handsome Solomon Islander, Callaghan's head field man"(31). Minnie describes their situation: "He Barney's boss. He boss the niggers in the paddocks....He tell the niggers, the damn Kanakas, the glory road and make them sing hallelujah. But Mary, she boss him. She teach him the glory road..." (48). Cindie has been told when she arrives that many eligible bachelors in the area are looking for a white wife, but she remains resolutely celibate throughout the book and represses her own sexuality, partly because of her attachment to Biddow, Snr. Minnie embarrasses Cindie, after she has commented disapprovingly that her husband is "only a boy!" by saying "He old enough," and after that she "smiled significantly, returned her pipe to her mouth and flashed a lubricious glance up at Cindie," who resolves to "keep her at a distance in the future" (48). ${ }^{18}$ Later, Toby equally embarrasses Cindie. When she wants to know what Mary says her problem with her husband is, Toby tells her succinctly in terms she has learnt from white men, and then comments, "You think me bad because I say words white man say. If I say black man's words you no understand" (56). ${ }^{19}$ Also talking about Mary's dissatisfaction with her husband,Barney Callaghan says to Blanche: "They've got a high moral sense about these things. A damn sight higher than some whites I could name. Mary is honest. We should leave them to their own customs" (57); and Blanche responds, "These people, niggers as they are, are married. Yet you would allow the woman to live with another man" (57). Ironically, Blanche will have a series of affairs with some

\footnotetext{
${ }^{18}$ Ironically, the old marriage plot is partially fulfilled in the ending of Cindie, when the maid (now become the manager) is about to marry the boss's son, ten years her junior.

${ }^{19}$ In beginning to work on the building of his own house, Biddow puts Tirwana in charge of his five men, and asks him to speak to them in "island talk." He says, "They know your talk, boss ... But ... I tell them in Mission jabber" (32).
} 
of the more disreputable characters in the area.

Minnie questions Cindie about her position in the Biddow household, and finds that she appears to be "the Toby, the Alice, eh?" (24). She also asks, "Your boss, he good to Kanaka, you think?" Cindie replies, "I don't know. He-he hasn't started yet" (24). When the Biddows move into their house, Folkhaven, they have one Aboriginal maid called Verbena.

Cindie has been observing Biddow's style of relating to the Islanders, which includes, for example, knowing and using their original names (rather than the Mary and Tommy Tanna that were habitual, 31), and begins to be "shaken from her assumption of innate superiority to these black-skinned folk"(53). With Biddow's second group of Islanders comes a woman called Charity (83), and it is in talking about her that Cindie tells Blanche she should avoid the term "nigger"-especially "in the hearing of a Kanaka. It spells trouble" (92).

Later, with the inevitable loss of Islander labour, Cindie draws Aboriginal workers into moving cedar logs down the river, "I don't think the Abo's have had a fair trial," she argues to Biddow, who suggests they are unsuitable since they "go walkabout" (157). Beginning to be persuaded, he asks: "Suppose you did get the Abo's to work, what about payment for it?" Cindie responds that this should not be in money:

They would not know what to do with it. They would spend it on drink, be cheated out of it by the whites. I would give them good food, buy them clothes, give them plots of ground and huts to live in. Things like mouth organs, too, things they could get pleasure out of. (158)

She also insists to Biddow that the Aborigines will be better axemen- "our blacks are more powerful than the Kanakas. Most of the Islanders are soft and flabby in comparison with our blacks" (170). Cindie is seen by the other white settlers at the Port as "one who possessed not only the ability of a man but, beyond that, some secret magic of her own in the handling of 'boongs"' (172). One of the original gang of Aboriginal workers, Billy, soon becomes the partner of the Biddows's Aboriginal maid, Verbena, and he gives his view of Cindie, "she like us. She just—-she alla same boong" (173).

Later in the novel, Cindie says to Biddow's son, Randy junior:

The blacks have educated me Randy...Their talk of the earth, the sea, the sky, of bird and animal life, their spirit worlds. I can't bother with the white workers somehow...(270)

Randy replies: "It's as though the primitive appreciation of nature and beauty has been wrung out of the white by civilisation, like wringing out a rag" (270).

Devanny's two historical canefields novels juxtapose ideologies about sexuality—or "customs" as Barney Callaghan describes them (57) — and begin to look at them from the outside through other eyes, or a style of whiteness lens. The central interest in the character of Cindie throughout that novel and, to a lesser extent, in the second novel modifies how far the critique of whiteness 
can go, since the authorial sympathy seems close to Devanny's own position ${ }^{20}$-and while there is sometimes a subtle irony in the depiction, it is often muted.

In the turn of the century context, anxiety about miscegenation was harnessed to facilitate the control and eventual deportation of the Islanders. A man named Melatonka arrives with the second group of Islanders that come to Biddow's station: "with the exception of Tirwana, he was the finest looking native she [Cindie] had ever seen" (93). "It was not the fact that he became sex-conscious whenever she approached him that aroused Cindie's ire and dislike. She detested him for his sharp detection of her own feeling about him and his knowing, perverted delight in it" (94). He disappears following Blanche's succumbing to him: if it were known by more people than Tirwana and Cindie, he would certainly have been hung for rape-or maybe just secretly shot. $^{21}$

What Moreton-Robinson categorises as "institutional practice within the centre," legislation in particular, was aimed at preventing Asians from establishing themselves economically. Since the 1850s, Chinese who came to Australia originally to work on the goldfields, and later moved into agriculture were for many Europeans competition, but for many Kanakas and Aborigines, fairer employers. In much of the popular press, leprosy was repeatedly connected with the Chinese, the Boomerang asserting in 1888 that "the Chinaman will eventually import, along with his sour, greasy carcase, some of the fearful plagues which have scourged the impure races of the East for so many centuries," and Lane's Worker warning in 1898 that, "A disease of such unspeakable loathsomeness is brought into our fair land with 'suitable' labour, brought here by cheap Asiatics and South Sea Islanders" (qtd. Evans 1975, 218). Such discourses were commonplace in these widely read papers. A climate of fear about leprosy was aggravated by the lack of medical knowledge about how it was caught; Devanny reproduces current dominant ideologies when her doctor character in Cindie implies that it is passed on by sexual contact, and Cindie similarly concludes that Blanche has been exposed to it through her liaison with Willis Fraser, whose partChinese wife Blossom has developed leprosy. ${ }^{22}$

When Cindie initially tries to cook for him, Biddow tells her that Lo How's "feelings might be hurt if I didn't eat the breakfast he will have prepared for me," Cindie asks, "Does that matter?" (43). In Cindie, some of the landowners employ large numbers of Chinese workers; on the neighbouring Montagues' station there are 50 Kanaka workers, and three times as many Chinese

20 This was considered by her CPA colleagues to be too sympathetic to the bourgeoisie, as well as not putting the appropriate position on issues of race, as she outlines in detail in Point of Departure (297-306). Devanny reports that Len Fox told her: "It's no good. You represent the Kanakas as living under a benevolent feudalism, when actually they were slaves and brutally treated" (297). She considered that "the book was rejected because it featured historical truth-when what was wanted was a spurious Uncle Tom's Cabin" (306).

${ }^{21}$ See Nancy Cato's Brown Sugar (1974), for example. There were very small numbers of such cases, however (Evans Exclusion 215-16).

${ }^{22}$ At the end of "You Can't Have Everything," Cindie encounters the same doctor thirty years after she had gone to visit Blossom. He tells her, "Fraser was a patient at the lazarette on the island off the coast when I visited there in 1916. He was too far gone for a cure." Cindie asks him about the two children, and the doctor says: They're all right.... After leaving here he put them in the care of compatriots of his wife and never saw them again" (386). 
(59). Some of the Chinese in the area are also engaged in business themselves. ${ }^{23}$ It is actually the labour of the Aboriginal and Asian workers that allows Cindie to go out into the fields, and eventually become the manager of the plantation, as a result of getting out of the house to work.

In Devanny's earlier novels set in Australia, Aborigines had been comparatively invisible, becoming important, along with Islanders, in Cindie, although the latter are never "men." No white sexual relations with "our Aborigines" - that historical secret of "the frontier" - are expressly depicted in Cindie; the rumours about Fraser and the Aboriginal women servants at his house are as close as this gets. ${ }^{24}$ But there are other cross-race sexual relations: as well as Blanche and Melatonka's single night, there is Fraser and his part-Chinese wife Blossom. Fraser is a character similar to Prichard's Sam Geary and Brumby Innes, and his relationships with his Aboriginal women servants are gossiped about (although he does not treat them as "well" as Geary does in Coonardoo). In "You Can't Have Everything," Cindie later recalls of Fraser:

"He was a beast of a man in some ways. Used to belt the life out of his Kanakas. Fed them on slops too, out of pigtins. He would throw food onto sacks and make them scramble for it. He didn't dare to move without a gun.

"I shall never forget his turning up at our Christmas party with the girl. The loveliest girl I have ever seen, doctor. You know how beautiful those half-Chinese girls can be. Sweetnatured too, despite that she was a prostitute. ... He married her to spite me. Treated her like a dog for a time." (387)

The white women's attitudes to the sexuality of other women are mixed up with their own sexual repression - or the dominant expectation of it. Early on, when staying with the Callaghans, Cindie "found herself entangled in a stream of coloured men coming up towards the house for their breakfast" (46-7); she observes, and tries to ignore, "the aloof glances of some, the interest of others, the sly lewdness of a small minority" (47). When Cindie first embarks on work in the fields, Blanche queries whether it is "proper" for her to "go over there with all those men," and Cindie responds: "as for the Kanakas - they're not men." Mary Callaghan corrects her: "Our women, Cindie, never forget that the Kanakas are men" (35). After a while, the white women in the household learn how to use guns — on the advice of Tirwana, who suggests: "That make the Kanaka think if he want too much the wife he left behind him" (84).

23 Cathie May's work on the Chinese around Cairns suggests that the Chinese played an important role in the local economy especially in agriculture, and were respected for their contribution and accepted more than in many other areas of Australia. In the early twentieth century in the Cairns area:

The Chinese were the district's sole suppliers of vegetables (and bananas in particular), serving alike individual householders, hospitals, sugar mills and visiting ships.... Tam Sie, for instance, supplied twenty tons of rice a month to the three sugar mills in the Innisfail district, while in 1914, Sun Wo Tiy was said to have a monopoly of stevedoring for the port of Cairns.... Cairns stands out for its close social relations with the Chinese exceptional by the standards of the day.... There are indications that the races also fraternised extensively at Cairns. (May 194, 206, 411)

${ }^{24}$ The most famous literary depiction of an Aboriginal woman by a white writer is, of course, in Prichard's Coonardoo (1929). Regarding this, the Bulletin editor, S.H. Prior, wrote to Vance Palmer on 9 June 1929 lamenting that "our disastrous experience with Coonardoo shows us that the Australian public will not stand stories based on a white man's relations with an Australian Aborigine ... There is no chance, I suppose, of your whitewashing the girl?" (qtd Healy 140). 
While they are still at the Callaghans, the Biddows go with them to attend a church service at which the Islanders join in the hymnsinging. Cindie, listening to it, is: "Humbled by its intrinsic beauty and chastened by a sense of shame in her own hitherto natural and simple assumption of innate superiority to these black-skinned folk" (53). Tirwana does not join in the singing, and Cindie wonders why.

There was something on his mind!

His mind! For the first time Cindie thought of the Kanakas as human beings like herself. People with minds. She thought of them as men but in a manner divorced from the significance given to that presumption by Mary Callaghan. 'They must think and feel like I do,' she thought. (53)

Blanche, while enjoying feeling "seigneurial," is also struck by the singing:

All the Kanakas could sing! ...

Yes, really, they were a good-looking lot -must have brains of a sort, too, to sing like that.

But maybe they sang like the birds ... with no real wit behind it. (52)

Irene, Blanche's daughter, later in the novel returns from Brisbane soon after the White Australia Policy has been put in place. She brings with her hostility to "fraternisation with the blacks and Chinese" (296), against which she inveighs: "In town no one associates with blacks and yellow men. And even here, Cindie, it's the same really. Underneath. If not, why do we have a separate carriage for the coloured men on our train?" (298). But she soon responds to her father's view, articulated forcibly:

"How can the setting of one race or nationality against another advance the conditions of the workers of any country? Tell me that! It can only assist the employing class of all countries to keep them down. Labour may be right in general but in this in particular they are playing the game of the most conservative of the tory class. Damned inhuman, I call it!" (296)

The complexities in the attitudes of different groups to each other are addressed by Cindie after the $\operatorname{riot}^{25}$ at the sports day provoked by a local redneck, Chris Martin, calling one of Islanders a "myall" (a term for an Aborigine). Cindie tells the Islanders, who are threatening to strike, that "the myall Aborigine is as good as you Kanakas any day. He's as intelligent as you are and he can work as well as you can" (310). To be persuasive, this needs amplification by Biddow, who argues:

"You blokes have learned your contempt for the Australian black from us whites. You

\footnotetext{
${ }^{25}$ For an actual event that was similar, see Moore, "The Mackay Racecourse Riot of 1883." An Islander was refused alcohol and it escalated into a mounted charge by 50-60 whites. This led to at least two confirmed Islander deaths, a higher number in other accounts. In the novel, this event occurs later in time, not long before the repatriations.
} 
know that we look after you people, in a sort of way. That policy pays us. You work for us ... But you see us treat the Aborigines like animals. You see them belted, shot at, driven from pillar to post ..." (310)

Charity interrupts to say that is not true of Biddow or Cindie; Biddow says, "No. But we are exceptions" (311). As the Islander worker, Sow, summarises Biddow's argument: "The white man, he all the time on top, if Kanaka he thinks he better than other black man" (311). When another Islander asserts, "The black Australian, he just like animal," Sow replies: "I see white Australian like animal too ... I see white Australian crawl on knees with drink."(311).

Near the end of Cindie most of the Islanders leave from the wharf during the compulsory repatriation, and a young man, kidnapped at the age of thirteen, speaks of how, at twenty, he is a stranger to his people, "But I do not want to stay here either. For here I have lived like a white man and yet I am treated like a horse. Because my skin is black! So what is there for me in this world?" (320) Tirwana responds:

"You, boy, people like you who can talk out loud what is in your hearts, you are lucky people. You are big people. You are leading people.... And I have seen the white man too, often thinks he is alone in facing up to problems. But it is only because, like you, he does not look around him and see the - the waiting in the hearts of the people who can't talk, how they wait on him who can talk, who can read their hearts and talk about it to the world ..."

"The white worker, he gets the small wage, the bad conditions, not because you are black men who want to work that way, but because he himself sees crooked. If the white workman gets more wages when you are gone, it won't be because you are gone but because he fights!... The white man who works and does not take the hand of the black and yellow man as brother is one damn bloody fool." (320-21)

With the repatriation of the Islanders, the narrative shifts back to the romance plot, and the novel ends with the impending marriage of Cindie and Randy Jnr.

“One Can't Have Everything" was begun in 1946, as soon as Cindie was finished. ${ }^{26}$ Bypassing the lead-up to and the aftermath of the First World War, it opens in February 1923 - producing a break in the narrative time between the end of Cindie around 1907_ and concludes at the end of the 1920s. The Islander, Tirwana, has remained with them in Australia, filling the role of the old retainer (29); Sow and Charity are the only other Islanders left at Folkhaven. Verbena, the Aboriginal maid (51) also remains in the household for the whole of the second novel's narrative time.

\footnotetext{
${ }^{26}$ There are several full MSS drafts. Quotations here are from JD/MSS/26/1 "One Can't Have Everything." In a letter to Miles Franklin, dated January 1946, Devanny asked for information on CSR (Ferrier 1992, 135-6). By March 1947 she had completed a draft (Ferrier 1992, 167), but in 1953 she told Franklin that the novel had "been waiting for completion for about seven years" ( Ferrier 1992, 310-11). It is possible that this was partly because of the hostile reaction of many in the Communist Party to Cindie when it came out in 1949, discussed by Devanny in Point of Departure (297-306).
} 
Cindy and Randy's neighbours at their new station, Valhaven, are impoverished compared to their previous, definitely plantocratic ones, reflecting the shift that was taking place to smaller farms. To the Venning wife, Cindie finds herself "flagrantly antipathetic" (60). When they come to visit, Mrs Venning sees Tirwana, "standing aloof, his great ebony body bare to the waist," and notices "his proportions, the proud set of his handsome head, the stance of his muscular legs. An unwholesome sexual appraisement took its place." Having first said, "My, what a big black man!" she then follows with, "What sort of a nigger is he?" to which question Cindie does not deign to reply (60).

Tirwana and Verbena miss little of what is going on, and are to some degree helpers and confidantes for the various members of their employers' families (for example, when Tirwana discusses with Cindie the views Verbena and Charity have regarding their pregnancies, 153). Tirwana appears to remain single throughout both books. When Inez, Cindie's daughter, who has married an Italian, Rin Diratto, goes into labour and the doctor and nurse have not arrived, she clings to Tirwana and "refused to permit the old man to leave her." This shocks the Italian neighbour, Mrs Cordello, who is also attempting to help, and she comments, "I never see before" (375).The degree of trust Cindie has developed in Tirwana is shown at the end of "You Can't Have Everything," when he remains in the room for the torrid interview between Cindie and Randy, and Bridie Brent, the daughter of a bankrupt former-neighbour cane farmer, who has become pregnant to Cindie's husband. ${ }^{27}$ Verbena is also listening to the whole thing, and comes up with what might seem to have been a solution to the white family's dilemma (413-4) -that Irene, Cindie's daughter, could bring up the baby. Biddow and Blanche have retired to a smaller home with two Aboriginal servants. When they went to visit, "Tirwana, whose appearance Biddow looked for as a matter of course, in view of his bulk, would ride," (376) while the others travelled in Cindie's car. "As the eldest of the family, he told Cindie, he liked to have them all under his eye" (377).

The workforce on the canefields, now European, includes considerable numbers of Italians, ${ }^{28}$ and they are politically divided, with the influential Catholic church on the side of Mussolini. After Black Hand supporters attack their neighbour Cordello, cutting off his ears, and Rin and Inez help him, Verbena turns lamps on in every room in the house: "The dagos, they act like bush boong" (97), she comments. At various points, when Verbena has seen Cindie strung out about Randy - who has spent the intervening years philandering — she has given her advice such as, "You go back to old days ... Young Randy he a born ram" (286). Randy later sees Cordello out on the road with a gun, ostensibly looking for pigs, and forces him to go home with Tirwana as an escort (141). Cindy sends Tirwana up to their other neighbours, the Brents, to help when Dan

\footnotetext{
${ }^{27}$ Randy has been trying to avoid Bridie, but when he finally appears she says, "Why haven't you been over? Why did you send the nigger?" He replies, "Bridie, how many times have I told you not to use that word," (261). He has been making use of Tirwana to give neighbourly help.

${ }^{28} \mathrm{~A}$ new political issue for Cindie in the second novel compared with race and ethnic relations at Folkhaven (where they lived in the earlier novel prior to the First World War), arises when they move to their new residence at Valhaven. This is "the foreign element. The problem it posed was entirely new to her. Masterman so far had not been invaded by what in this area were alluded to as "dago hordes'" (53). This is a period of "thousands of immigrants," mainly Italians; for Cindie, "It was one thing to disapprove of an immigration policy, another thing altogether to classify white men as blacks." (54)
} 
Brent becomes ill, and also promises Verbena to assist. But there are many things that Tirwana cannot do, since Islanders were banned from engaging in most types of skilled labour. He cannot, for example, drive the cultivator for the Brents because, "He's had no practice at the work" (284).

Inez has had one novel accepted, and discussing her planned second one with her husband, Rin, she analyses with him the reasons for the assumption that "the Aussies are superior to foreigners." She blames the convict forbears, prefiguring Miriam Dixson: "'Most of them were illiterate, knew only brutal and depressing standards of life. They could not have brought to this country any real knowledge, could they?" On the other hand: "They found that they, the descendants of outcasts from Europe, were able to build a civilisation out of nothing, as it were" (324). In dialogue with Biddow, Inez develops a comparative view, stemming from some of Devanny's own reflections, "I have heard New Zealanders decry Australians for their overdeveloped ego, but if the more or less educated rural and yeoman stock of Britain that settled New Zealand had been given the job of breaking in Australia, they might not have made such a good job of it." Nonetheless: "once you've said that, then you are faced with the inevitable, unenviable development of such a people. Both individually and nationally, isolation precludes progressive thought" (325).

Cindie recalls the past to her granddaughter, Inez, cogitating on how "the kanakas stuck in her mind more real than her own countryfolk, the Aborigines." She says to Inez, "Those were the days, love. Life in the canefields now is drab and uninteresting compared with the days of the kanakas. A spaciousness, a romantic glamour, overlaid the days of the great plantations. The kanakas were fine people too. Friendly and companionable. Trustworthy to the nth degree" (163). National and Queensland policies held back the Aboriginal people, although political activism was stirring with, for example, the organisation of a Day of Mourning on 26 January 1938 by Aboriginal activists including William Ferguson. ${ }^{29}$ The Bringing Them Home Report, among many other sources available now, provides information about the interventions of figures such as the Chief Protector and Director of Native Affairs, from 1913-1942, J. R. Bleakley (who had his early training in the Torres Straits). Little of the actual violent suppression and "dispersal" of Indigenous people appears in either novel; there is only the brief reference in Cindie in the debate after the "riot" by Biddow to their family's treatment of Aborigines being "an exception" to the habitual practices of almost all other whites. In "One Can't Have Everything," Cindie muses regarding the Islanders:

They had vanished like the Aborigines themselves, who had had perforce to flee before the threat of hunger from the destruction of their coastal feeding grounds, and the refusal of the whites to regard them as human beings. Later, the insignificant remnants of once flourishing splendid tribes had been more of less forcibly segregated in a motley collection of 'Missions'....

Yes, Cindie had fought for the Aborigines as she had never fought for the kanakas, Yet, so unobtrusive had been their presence, so soft and unforbidding their personalities, so at one with the deep silence and depths of the jungle forest, as compared with the powerful, highly developed Melanesians, that as individuals they had almost

\footnotetext{
${ }^{29}$ See Morgan and Bostock's film Lousy Little Sixpence, which includes old footage.
} 
ceased to hold meaning for her. (384)

Later again in the novel Cindie remembers, "How Blanche had hated the Kanakas. Hated Tirwana" (310). She dwells on her yearning for the past:

The strong black bodies against the gold of the cane, the richness of their song, the impact of their extraordinary intelligence, their sensitive reactions to the natural world. Her dreams and plans of those old times seemed in retrospect to be fantastic. Dreams of schools for the shy little brown wood-pigeons; dreams of the original Australians marching side by side with the white invaders to a land of happiness and plenty. They had not endured for long, those dreams, soon they had dissolved into the miasmic mists given off, like stench from a rotting corpse, by the "inspired" doctrines of White Australia. (383-4)

The difficulties that Devanny encountered in drawing "pioneer women" may have something to do with the constrictions of the "pioneer legend" as Larbalestier discusses it: "versions of the pioneer legend and the legitimacy of Australia as a settler colony have combined to generate ways of imagining Australia that submerge inevitable outcomes of colonisation irrespective of the motives, or individual characteristics of the settler" (26).

Another novel relevant to considering black labour in relation to white settlers and their perceptions of their own whiteness, is the one Devanny wrote towards the end of the 1940s and set on Thursday Island, "The Divers, the Devil and Pan" or "Pearls and Baroque." She lived on the Island herself in November and December 1947. Devanny's political orientation to the situation of the Indigenous people on Thursday Island, constrained and oppressed under the Torres Strait Islanders Act of 1939, comes over clearly in four articles in the Tribune, and the longer manuscript from which they were drawn. ${ }^{30}$ They spell out clearly the paternalistic Protectorship under which the Islanders operated - although some of the white dominance had been eroded during the evacuation of all Europeans from Thursday Island during the Second World War. When Lonce Rose arrives on the Island just after the War, he is told by an old man on the wharf, "All the coloured blokes are engaged on their own luggers: them that's not working on Company or privately-owned luggers, that is" (4). Lonce comments to his father, Buck Rose, when he finds him on the boat he used to captain, "Funny, you know, dad, seeing all these Islanders and Mixed-Bloods on the job. A change from the old times, when the Japs ran the show" (11).

It might seem paradoxical, given Devanny's interests in race and labour relations, that the central

\footnotetext{
${ }^{30}$ The titles of the Tribune articles in February and March 1948 indicate their politically interventionist stance: "I Discovered Disgraceful Jim Crowism on Thursday Island"; "Labor Must End Thursday Island's Jim Crow Scandal"; "Color Bars Hit Health on Thursday Island"; "Torres Strait Islanders Need a New Deal." However, there is no character in "The Divers" who articulates such an analysis. For more detail of the Tribune articles, see Ferrier 1999, 243-5. Rather than the bigger issues, in the novel it is specific examples such as the segregation of the cinema that the narrative foregrounds: for example, when Lonce takes Pan Leslie to the cinema, they sit in "the roofed-in balcony reserved for Europeans and the Chinese business community" (111).
} 
theme of the novel might appear to be the alcohol addiction of two important white characters: certainly much of the plot is played out around this. One of the two is Flora Payton a charismatic Spanish-Scots woman. She has come to the Island with her husband and young son, and it rapidly emerges that she has a severe alcohol addiction that nothing will stand in the way of when she gets "a spell." Pan Leslie, the stepdaughter of Jake Swinnerton, a neighbour of Mabel Rose, takes Flora in hand and tries to cure her.

The other person much more consistently dysfunctional through alcohol addiction (or, as described to Lonce by Bano, "rot-gutted with booze," 7) is the white pearler Buck. He has one son, Favid, with an Islander woman, Ama Solomon (Favid accordingly having the status of "Mixed-blood," 25), and one son, Lonce, with his white wife, Mabel. Lonce has returned to Thursday Island after being a merchant seaman during the War (28), and wonders if he can reconcile with his family and perhaps work in pearling. He finds that his half-brother Favid has become captain of the pearling lugger on which Buck is still employed as cook and engineer despite his quite advanced debilitation. Lonce manages to get taken on, after he gets support from Favid's half-brother, Bano, who has a Filipino father (8).

Lonce, when he returns, is not covering up his connections to Torres Strait Islanders. On board Swinnerton's pearling boat, when Jake says: "Except for the colour you and Bano could be brothers," Lonce tells him that they actually are. Bano is uncomfortable with this, and says, "It's not good to tell things like that to a man like Jake here" (39). When they later go to the cinema, Lonce leaves with Ama Solomon and Bano, saying to Pan's mother that he supposes that Jake, her new husband, "will have told you that Bano's my half brother" (112). Jake replies, "Matter of fact, I hadn't mentioned it." Such things are not the topic of ordinary conversation on the Island, though they are the subject of much gossip. Pan is amazed to suddenly hear this, and initially says, "But he's a coloured man. How can he be?" However, she is quite devoid of essentialist racism (although perhaps not power evasiveness) and thinks:

Lots of people would hate it-Mrs Payton for one, she bet-but she herself wouldn't care if he produced a whole tribe of coloured relatives. (112)

Lonce was earlier attracted to Flora but becomes disgusted by her excesses, and the desperation of her child. Another draft of the novel expresses some of Lonce's responses to Flora rather more crudely; at one point he muses that it "would serve her right if one of the buck boongs ran amok with metho and did her over" (JD/MSS 25/2,111). This is one of the few occurrences of the pejorative language that peppered the speech of whites in the canefields novels when they spoke of or to people of other races; generally the non-whites in "The Divers" are referred to as "coloured" or "Mixed-bloods." There is also little swearing indicated among the blokes on the boats, just the occasional "so-and-so." 31

Flora is also blithely unaware of racial tensions, as well as the conventions through which these are camouflaged on the Island. Lonce and the Swinnertons are invited by Bano to the Islanders

\footnotetext{
${ }^{31}$ This may be with an eye to publishers, since it is hardly realistic. In the earlier canefields novel, Sugar Heaven, published by the CPA's Modern Publishers, the workers' speech was heavily interlarded with dashes, indicating expletives.
} 
Club before the midnight service at the Catholic cathedral at Christmas, after Pan has expressed an interest in going. Flora gatecrashes the Club, the worse for alcohol, and disrupts the restrained and courteous interaction (114).

Ama Solomon is among the Islanders who "for one reason or another were exempt from control by the Queensland Government, and lived the year round on Thursday Island" (222); though thinly drawn, she is a character of strength, and a power in her family. Mabel has rejected her husband, but Ama is willing for Buck to come and live at her house when the Wet comes on and he cannot stay on the boat. When some of the whites come to visit her, she holds her own: "They come to see ME ... these white women" (194). She asks them, "What you do with me? I the coloured woman. I only n-a-t-i-v-e. Scornfully she drawled out the final word" (196). This embarrasses Favid, and he lets loose "a torrent of admonition at his mother in their Island tongue" (196). Ama retorts:

"Favid ... he say I make shame but I not mean nothing. The words just spit out of my mouth. You pretty woman there [Flora], when you say you come back I think: she too smart to mean it, she just being polite. So I polite in my way." Throwing back her head she opened her mouth wide, displaying snowy perfect teeth, and emitted screech after screech of laughter. (197)

All are drawn into laughing, "Favid, however, seemed startled by the sound from his own lips. Drawing his feet sharply beneath his stool he looked around as if caught in an illicit act" (197). The relationship between the different ethnic groups on the Island is, it seems, very much bound by conventions, and certain public silences. ${ }^{32}$ Buck's wife, Mabel, estranged from her husband, has an extremely cynical view of the sexual and racial politics on the Island:

"Men are what they always were: lecherous, vile, seeing nothing in women but sex. You think I don't know? Look at the state of things on the island: men with wife number one and wife number two! And chasing after the black women into the bargain." (28)

\footnotetext{
${ }^{32}$ As an example, at Bano's wedding, the reader is informed that, "Tacitly, it was understood by all that white women did not dance with 'colour,' though the reverse was an acceptable convention" (223). Flora is particularly pushing these conventions when, drinking alone in a pub, she invites some "Mixedbloods," who are covertly watching her, to have a drink (186).
} 
Mabel initially wanted Lonce to leave the Island when he arrived, or at least to marry a white woman- "It would keep you safe, if you have any decency in you at all, from these- these black harpies" (28-9). While Lonce helps her to some degree of overcoming her bitterness, little is resolved. However, in a perhaps rather strained happy ending for the romance plot, Lonce eventually proposes to Pan, the "respectable" and restrained ${ }^{33}$ white woman, dubbed by her stepfather "Salvation Army Sal" for her role in more-or-less rehabilitating Flora who marries Max Wilson, a pearl dealer.

At various points in both of Devanny's historical canefields novels, Cindie and "You Can't Have Everything," and also in "The Divers," we can observe a conflict between the industrial plot, the racial and ethnic relations plots, and the romance or gender plots, in terms of where the interest lies. The ways in which these compete for attention may be partly due to Devanny's sense of her audience (or maybe of different audiences, to which her different books, or different parts of them, might appeal); there were also pressures from her Communist Party critics as well her publishers, as she struggled to get out more novels as the 1950s approached. In relation to her earlier-published cane industry novel, Sugar Heaven, set close to its time of publication in the mid-1930s, Devanny recalled that the CPA leader, J. B. Miles, "liked the political aspects of the book so much that, for once, he withheld criticism of my handling of the sex question" (Point of Departure 193). Handling the sex question would remain a central concern in all her novels. In relation to the tradition of committed writing, within which Devanny was working, the thinness of Indigenous characterisation in her two historical canefields novels discussed above may have something to do with Indigenous people working for little or no pay in the earlier years of colonisation, and the levels of Aboriginal participation in class struggle being not very publicly visible until the 1940s stockworkers' strikes. These struggles for pay and recognition were taken up by Frank Hardy, and by Dorothy Hewett in works such as her poem, "Clancy and Dooley and Don McLeod" - when they become a suitable subject for the kind of "industrial novel" that socialist realists, especially those who were Communist Party members, were supposed to write. Unfortunately, the CPA and the Realist Writers were never going to help Devanny publish "You Can't Have Everything," and commercial publishers did not like it either.

Complex political and social contradictions existed in the periods in which Devanny set, and wrote, her two historical novels of the canefields, and her contemporary pearling novel. Sara Ahmed suggested in 2004:

Whiteness studies should involve at least a double turn towards and away from those bodies who have been afforded agency and mobility by such privilege...the task for

\footnotetext{
${ }^{33}$ One intriguing aspect of the presentation of Pan is her interaction with domestic violence, not something generally mentioned with an approval in Devanny's fiction. Part of Pan's approach to "minding" Flora is to physically fight with her; when Pan becomes desperate about trying to restrain Flora from sneaking bottles of gin into her mother's house, she seeks for a solution: "Max Wilson wants to marry you. What about that way out?" When Flora replies, "He's got no backbone. I could do as I liked with him," Pan becomes furious and responds: "What you need is a father of a hiding .... What you need is to be beaten up" (247). Pan's stepfather Jake is also accustomed to keeping his son Ralph under control with physical violence; the threat of "a clip on the ear" from Jake, "which Ralph knew meant more than the mere words implied" (252-3) is enough to ensure his compliance.
} 
white subjects would be to stay implicated in what they critique, but in turning towards their role and responsibilities in these histories of racism, as histories of this present, to turn away from themselves and towards others. (59)

The degree to which Devanny was able to develop an, albeit conflicted, critical whiteness lens for viewing these contradictions, and by turning "towards, and away" from white "chauvinism" to offer some view of it from the outside, or the standpoint of the other, in her fictional practice is striking and innovative, given the time and place.

\section{Works Cited}

Ahmed, Sara. "Declarations of Whiteness: The Non-Performativity of Anti-Racism." Borderlands 3.2 (2004).

Anderson, Warwick. The Cultivation of Whiteness: Science, Health and Racial Destiny in Australia. Melbourne: Melbourne UP, 2002.

Bartlett, Alison, Robert Dixon and Christopher Lee, eds. Australian Literature and the Public Sphere. Toowoomba: ASAL, 1999.

Borch, Merete Falck, Eva Rask Knudsen and Martin Leer, eds. Bodies and Voices: The ForceField of Representation and Discourse in Colonial and Postcolonial Studies. Amsterdam: Rodopi, 2008: 203-20.

Cato, Nancy. Brown Sugar. London: Heinemann, 1974.

Cilento, Raphael. The White Man in the Tropics, with Especial Reference to Australia and its Dependencies. Issued by the division of the Commonwealth Department of Health Under the Authority of the Minister of Health. Melbourne: H J Green, Government Printer, 1927.

Commonwealth of Australia. Bringing Them Home. Human Rights and Equal Opportunity Commission, 1997.

Devanny, Jean. The Butcher Shop. [1926]. Auckland: Auckland U P, 1981, intro. Heather Roberts, with a note by Bill Pearson on its banning.

----. Cindie [1949]; London: Virago, 1986, intro. Carole Ferrier.

----. Lenore Divine. London: Duckworth, 1926.

----. Point of Departure: The Autobiography of Jean Devanny. Ed. Carole Ferrier. St Lucia: U of Queensland P, 1975. 
----. Point of Departure, ed. Carole Ferrier with an Epilogue by Pat Hurd, U of Queensland P, 1986.

----. Sugar Heaven.[1936] Sugar Heaven: A New Scholarly Edition. Ed. Nicole Moore. Melbourne: Vulgar Press, 2002.

Dixson, Miriam. "Stubborn Resistance.” Iremonger et al eds. Strikes, 129-142.

Evans, Raymond. "Anti-Chinese Riot, 1888." Evans, Ferrier and Rickertt, eds., Radical Brisbane. Melbourne: Vulgar Press, 2004, 66-70.

Evans, Raymond and Carole Ferrier with Jeff Rickertt, Ed. Radical Brisbane. Melbourne: Vulgar Press, 2004.

Evans, Raymond, Kay Saunders and Kathryn Cronin. Exclusion, Exploitation and Extermination. Race Relations in Colonial Queensland. Sydney: ANZ Book Co., 1975.

Ferrier, Carole, Ed. As Good as a Yarn with You: Letters Between Miles Franklin, Katharine Susannah Prichard, Jean Devanny, Marjorie Barnard, Flora Eldershaw and Eleanor Dark. Cambridge: Cambridge UP, 1992.

----. Jean Devanny: Romantic Revolutionary. Melbourne: Melbourne UP, 1999.

----. "Modes of Consumption and Reception." Hecate 9.i/ii (1983): 160-166.

----. ' 'Never Forget That the Kanakas Are Men.' Fictional Representations of the Enslaved Black Body.” Borch, ed., 203-220.

----. "Sugar Heaven and the Reception of Working Class Texts." Hecate 11.i (1985): $\quad$ 19-25.

----. "The Uses of Whiteness Theory in Critical Discourses of Race." Bartlett et al, eds., 1999:163-171.

----. "The Working Class Novel in Australia: Katharine Susannah Prichard and Jean Devanny." Katharine Susannah Prichard: Centenary Essays. Ed. John Hay and Brenda Walker: 1328.

Frankenberg, Ruth. White Women: Race Matters. London: Routledge, 1993.

----. Displacing Whiteness: Essays in Social and Cultural Criticism. Durham, N C: Duke UP, 1997.

Hay, John, and Brenda Walker, eds. Katharine Susannah Prichard: Centenary Essays. London: U of Western Australia and Australian Studies Centre, 1984. 
Healy, J.J. Literature and the Aborigine in Australia. St Lucia: U of Queensland P, 1978.

Hewett, Dorothy. Wild Card: An Autobiography, 1923-1958. Ringwood: Penguin, 1990.

Kellett, John. "The Boomerang." Evans and Ferrier, eds. Radical Brisbane. Melbourne: Vulgar Press, 2004, 71-77.

Kidd, Ros. "The Price of Justice." Hecate 22. 2 (1996): 67-78.

Larbalestier, Jan. "White Over Black: Discourses of Whiteness in Australian Culture." Borderlands 3.2 (2004).

May, Cathie. Topsawyers: The Chinese in Cairns 1870-1920. Studies in North Queensland History No. 6. Townsville: Department of History and Politics, James Cook University, 1984.

Menghetti, Diane. The Red North. Townsville: James Cook UP, 1981.

Moore, Clive. "Kanaka Maratta: A History of Melanesian Mackay.” PhD thesis, James Cook University, 1981.

----. “The Kanaka Racecourse Riot of 1883.” Web.

Moreton-Robinson, Aileen. "Unmasking Whiteness: A Goori Jondal's Look at Some Duggai Business." Queensland Review 6.1 (May 1999): 1-7.

Morgan, Alec and Gary Bostok. Lousy Little Sixpence. Doubletake, 1983.

Murphy, D. J., ed. The Big Strikes: Queensland 1889-1965. St Lucia: U of Queensland P, 1983.

Nicoll, Fiona. "Pseudo-Hyphens and Barbaric/Binaries: Anglo-Celticity and the Cultural Politics of Tolerance." Queensland Review. 6.1 (May 1999): 77-84.

Nilsson, J. A. "Mackay in the Nineteenth Century." Journal of the Royal Historical Society of Queensland 7.2 (1964): 355-67.

Prichard, Katharine Susannah. Coonardoo (The Well in the Shadow). London: Jonathan Cape, 1929.

----. Golden Miles. London: Jonathan Cape, 1948.

----. The Roaring Nineties. London: Jonathan Cape, 1946.

----. Winged Seeds.London: Jonathan Cape, 1950.

Rothwell, Nicholas. "Mapping the Massacres of Queensland Aboriginal Society.” Rev. of 
Timothy Bottoms, Conspiracy of Silence: Queensland's Frontier Killing Times. Australian 29 June 2013.

Stevens, Joyce. Taking the Revolution Home: Work Among Women in the Communist Party of Australia, 1920-1945. Melbourne: Sybylla, 1987.

Syson, Ian. "Tracing the Making of Australian Working Class Literature." PhD Thesis, English Department, U of Queensland, 1993.

Voices of Melanesia. “Australian South Sea Islanders (Kanakas) \#1.” Web. Accessed 20.11.13. 